\title{
Bold Indigenous Women Working for the Conservation of Orangutans in Sarawak, Borneo
}

\section{Christina Yin}

Swinburne University of Technology, Sarawak Campus

\begin{abstract}
$\mathrm{M}$ ujan Anyie rummages in the battered grey suitcase in her parent's bedroom. She's alone in the family bilik (room) at the longhouse, Uma Lesong, in Belaga. Her sisters are away and her parents are tending their vegetable patches in the forest. They will be spending the night in their hut there. Under some old clothes, she finds a book with a green hard cover. It is the only book she has ever seen in her home. Her father's handwriting in Kayan fills the pages. She knows it can only be his handwriting. Her mother never went to school.
\end{abstract}

Her father went to school until he was about 15 years old. Since then, his life has revolved around subsistence farming and a little hunting on the side. In the old days, girls had to help with the farming and to make handicraft to sell so their brothers could be educated. Only later, when people realised how important education was, did families sacrifice so their daughters could attend as well. Mujan Anyie's mother's younger sisters were fortunate enough to go to school.

By now, Mujan Anyie herself has had enough schooling to have learned to read Malay and English. She's curious. What is this book? It's not like the story books or textbooks from school. There are lists of things to buy, and then she reads something that makes her stop flipping through the pages. Although Mujan Anyie knows she was not always the eldest in the family, she has few details about what happened to change that. All she knows is that when she was four, her older brother and sister drowned while bathing in the river with friends.

Now, reading her father's words, she learns how he felt when his two first born children drowned. She reads about his sadness and desperation; how he wanted to kill himself. As she reads, Mujan Anyie cries. Her father has never shown any love in words or in actions. He does not hug or kiss, not even when his children were young. But now, Mujan Anyie knows that he does have feelings, and that he loves his children deeply. She reads the words over and over until her tears blur the page. She closes the book and tells no one what she has read, what she now knows. 


\section{Mujan Anyie, Researcher, Orangutan Team}

\section{First School}

Mujan Anyie is seven years old when it's finally time for her to join the older children at school. She wakes up at 5:00 a.m., has breakfast with her parents and younger sisters. It's not just the first day of school; it's the first day of her life away from her family. The school is a residential school so she won't see her family for a few weeks. She, and all the other primary school-aged children in the longhouse, will leave today, the Sunday before the start of the school year because it's a five-hour walk to Sekolah Kebangsaan (National School) Long Gang from Uma Lesong. It can't be done every day. The Primary 1 children like Mujan Anyie walk behind their seniors who know the way. Like the others, she's wearing a t-shirt, shorts and slippers. On her back, she carries her new backpack bought from the little shop in the nearest town in Asap; the anime character Sailor Moon smiles at the children walking behind her.

When she arrives at school, she's given a place in the girls' dormitory. Thirty mattresses with yellow and green flower patterns are laid out on the floor. What's amazing is that there are six meals a day! She has never had so much food every day, and so regularly. She has a breakfast of donut or porridge, tea and Milo at 6:00 a.m.; tea break of crackers and coffee at 10:00 a.m.; lunch of fried chicken, vegetables and rice at 12:30 p.m.; another tea break of juice and more crackers at 3:00 p.m.; more meat, vegetables and rice for dinner at 5:30 p.m.; and finally supper at 9:00 p.m., lovely Milo, coffee or tea with crackers and donuts before bed!

She learns English and Malay, the national language, and she learns to read. It's the year 2000, the new century and here in Belaga, the language of instruction is still English. In other parts of the country, lessons are in Malay. But Mujan Anyie doesn't know this; what she does know is she's learning so many new things. Her favourite subject is geography. She had never known that the world was so big. Mujan Anyie wants to visit every country in the world.

\section{Further Away from Home}

When she's thirteen, Mujan Anyie goes to a new boarding school, Sekolah Menengah Kebangsaan (National Secondary School) Bakun, Belaga. In secondary school, there are new subjects and she discovers Kemahiran Hidup, Living Skills. The best part is learning to grow plants. First she learns to grow flowers like the brilliant red and pink ixora. Then she learns to grow vegetables like ladies' fingers, eggplant and long beans. Some of the children eat the vegetables, but Mujan Anyie sells them to the teachers. This helps when she needs to buy school shoes or clothes to replace those she's outgrown.

Each move to a new school takes her further from Uma Lesong. After the Form Three government exams, she's placed in the science stream so she has to move to SMK Belaga, a school that is equipped with science laboratories. This time, she and her friends leave Uma Lesong at 5:00 a.m. to get to the jetty in time to catch the express boat to the school. It's a 
one-hour ride on the river, Sungai Asap, and Mujan Anyie loves to sit on the deck, feeling the early morning air on her face.

She has to move again two years after that because she's enrolled in a Matriculation course at Labuan, an island federal territory near Borneo. During this time, her parents, too, move. They go further into the interior near where the original longhouse stood before it was flooded by the Bakun Dam project. The land they were given at Uma Lesong where they and the other longhouse folk were relocated <by the state? government? > is not enough to sustain them all. Mujan Anyie's parents return to what is now an island to start building their own small longhouse where they can cultivate some land. This place, Jawan, is two hours by boat from the Bakun Jetty, which is another hour's drive to Uma Lesong. When they meet during school holidays, it is at the family bilik in Uma Lesong.

Before she leaves home yet again for university in Sabah, she looks for the little book with the green hard cover. She shows it to her two younger sisters and lets them read it so they will know their father's feelings. They cry together. Many Kayan people only recognise the sons in a family. There are no more sons in Mujan Anyie's family; Billy, the only son, and Sity, the oldest girl, are gone. Mujan Anyie, the eldest since she was four years old, bears the hopes of her parents, being the one to break the path through the forest to lead her sisters through.

Three years later, she is the first in her family to graduate from university. Her parents travel from Jawan on their small longboat to Bakun Jetty. From there, they travel by land to Uma Lesong, and then on to Bintulu using a rental van. They take their first flight from Bintulu to Kota Kinabalu to attend her graduation.

Today, she's working as a researcher on the orangutan team based in the Kuching office of the Wildlife Conservation Society, an organisation based in New York. Waking up in the early morning and breathing in the cool, fresh air in the forest is the best part. She believes that someone has to stand up for the natural world. She loves to hear nature speak even if she don't know the meaning.

\section{Selena Nala, Researcher, Orangutan Team}

Arriving for her first day at the Wildlife Conservation Society (WCS) office, Selena Nala wonders if she's had too many failures to deserve her job.

She can't believe that she has a job in an international conservation organisation with its headquarters in New York. The only child in her family to have graduated from university, she's suffered for three years not being able to secure a government job. Despite multiple successful job interviews and offers from the private sector, her parents had persuaded her to decline them in favour of waiting for openings in the civil service. Both her parents work in the civil service in their hometown Sarikei; her father as an officer in the Customs Department and her mother as a clerk in the Sarikei District Council. Like many indigenous people, they believed that a government job is the pinnacle of success, and, with her undergraduate degree 
from Universiti Malaysia Sabah, they expected her to obtain a plum position and be set for life with a steady income and secure pension.

After the euphoria of graduating from university had waned, Selena Nala started applying for jobs. She received a rude shock when her mother told her that she would not get any support from the family if she wanted to attend an interview for a position in a timber factory. Though the job was related to her Bachelor of Science in Forestry Technology and Industrial Wood Fibre, it was an offer from a private company and was believed to not be a good opportunity to pursue. After many applications and interview offers from private companies, and rejections from the Customs Department and other government positions later, depression set in, and Selena Nala found herself gaining a phenomenal amount of weight. Sitting in front of the TV and snacking on comfort food, she hid herself from the outside world. She could not bear running into family friends and acquaintances who would ask, "So what job do you have now?" or "Don't you have a university degree? Where are you working now?"

One day, she came across a weight loss programme on television and decided that she would try to follow it. She had nothing else to do, so she joined a gym and started to use the machines to lose weight, get stronger and fitter. Over the next two years, she spent two hours a day, five days a week in the gym. In that time, she lost 21 kilograms, but she was still unemployed and living at home, hiding herself from the outside world. Finally, in 2016, a 7-Eleven opened up in Bintangor. Without telling her parents, she applied for a position as sales assistant and to her amazement, she was successful. This time, her parents didn't stop her from taking the job. Perhaps they had finally realised that a government job was not going to be forthcoming. Selena Nala learned everything she could from the 7-Eleven store manager, from taking stock of deliveries to handling belligerent customers on the night shift. She took pride in the job, but she was still a graduate who could only be a sales assistant.

At the end of the year, a friend told Selena Nala about a job vacancy in the Wildlife Conservation Society. She applied but did not expect to be considered. To her, the three-year gap in her resume screamed of failure and shame. However, in December, she received an e-mail and an invitation for an interview. This time, she had to travel all the way to Kuching, a five-hour drive from Sarikei. Her mother didn't stop her. In fact, the whole family and cousins accompanied her to Kuching. Driving in two cars, they made a holiday of it. She could hardly believe that she was on her way to an interview for a job as a researcher for a conservation organisation based in New York City.

Waiting her turn at the WCS office, she spoke in the local Malay dialect, Bahasa Sarawak, to the young man helping to prepare the interviewees. "My English is so poor. How can I manage in the interview? How can they want me?"

The young man just smiled at her and said, "Maybe your English is not so good, but you have other skills that are good." This simple response perked her up and when it was her turn, she found she could speak freely in the interview. She just opened up and answered every questions as honestly and directly as she could. 
Then it was time to go home. She was told that she would be contacted if she were selected for the next step, the field test. The next few weeks were hectic. She was working the night shift at 7-Eleven and handling rowdy customers in the middle of the night on her own was exhausting. About three weeks later, while she was asleep during the day, the same young man who had boosted her confidence just before her interview called. "Have you checked your e-mails recently?" he asked. And when she said she had not, the young man said, "You should. Please check your e-mails and reply."

She had been selected for the field test; a trek up Mount Santubong. Along with five or six other candidates, Selena Nala climbed. Despite all the work at the gym, her legs cramped and she was the one who held everyone up. After three hours of trekking, no one could reach the peak of Santubong because of her. There was nothing she could do but put on a positive, smiley face while she rubbed her aching muscles.

Eventually, they all climbed down from half way up the mountain, and she believed she had failed yet again. Unable to speak English well, unable to maintain the physical fitness required for the field work, unable to meet expectations once more. She went home to Sarikei, back to what she felt was more shame.

So after all that excitement-the call to the interview and the field test; facing the interviewers and then the fellow applicants-there was nothing. She was back at work at 7-Eleven and always on the night shift. Then she received another phone call. She could hardly believe it. She had a job offer! So, on her first day of work at the beginning of the new year, she arrives early at the WCS office, and stepping out of her car, she says to herself, "I've had so many failures. Do I deserve this?"

She still can hardly believe it when she wakes up each day. Working on the social side of the orangutan team, she meets the longhouse people and talks to them about their lives, their livelihood and cares, their views on the orangutans and their habitats - the forests they share. Selena Nala has grown up in Sarikei. It's a small town even by Sarawakian standards, but to the longhouse folk, she's from the city. Her Iban gives her away; it has been diluted from living in the town. She asks them questions politely, humbly, remembering her father's advice to never treat others poorly no matter their rank. She's learning so much from these people in the interior.

It's the end of January. Her first month of real work is nearly complete. She receives her first pay cheque and decides to treat herself to a bowl of noodles. She goes by herself to a Chinese coffee shop at Jalan Song. She loves noodles with minced pork and cold Chinese tea. A friend had brought her here to eat when she first came to Kuching. Now, she pays for it with her own money from her first pay cheque. Five ringgit fifty sen for a bowl of kolo mee "special" including shrimp, liver, fish balls; it's the best meal she has tasted since graduation! 


\section{Foon Yuan, Assistant Coordinator, Orangutan Team}

Foon Yuan hugs her husband and nuzzles their baby in his arms. She strokes the soft skin on his cheek and gives the baby a last kiss before walking up to the airline attendant at the departure hall. She hands over her boarding pass and passport to be checked, then once allowed, walks through to queue at the baggage scanners. She looks back at her husband and baby, but after she's through the immigration screening, she can't see them anymore. It's the first time she's going to be apart from the two-month old baby, and the first time she's travelling overseas. Her breasts are already tingling. She's going to have to express her milk and store it safely during this two-week trip. This will have to be done discreetly during the training. She's going to Bangkok to learn from the WCS Thailand team about enforcement and patrolling in conservation areas.

"Go ahead," her husband had said. "I'm not travelling, so I can look after the baby. You go to Thailand." And so she does.

"A girl has to be able to look after the home, family and do everything a man can do." This is what her Bidayuh mother told her years ago when she was a girl. "When they go hunting, they'll disappear for three to five days, so if a girl can't do what a man can do, how is she going to survive later on when she gets married? So it's basically about survival and being able to look after yourself." It is no different in Kuching town where Foon Yuan grows up. While her brothers are in the arts stream, Foon Yuan's grades place her in the science stream. The family is happy for her, but her Chinese grandmother tells her, "Don't become a doctor." (Why? One of her other grandchildren is a doctor and she saw what he had to go through to become a doctor. "It's good money in the end, but what kind of life is that? I want my grandchildren to enjoy their lives.") At first, Foon Yuan wanted to become a vet as she loves animals, but her grades, though good, weren't good enough. Disappointed at first, when she comes across the option for Animal Resource Science and Management at Universiti Malaysia Sarawak, she realises it's the right course for her.

At school, she's considered special. The teachers think highly of children of mixed ethnicity. There are no difficulties having a Chinese father and a Bidayuh mother. Nor any at university, where, after having all her education in Malay, she's relieved that everything is taught in English. Her professor is the one who tells her about WCS Malaysia and suggests that she applies for a job with the NGO. She does when she's in her final year and gets a part time job as a researcher. When she graduates in 2006, she begins to work for WCS full time.

Foon Yuan meets her husband at WCS; he's a true naturalist: a field photographer and one of the best birders in the state. Foon Yuan is expecting her first child when she is still new to WCS, but her boss tells her it's okay. She can work in the city, and doesn't have to go on field trips. But to Foon Yuan, those are the best part of the job. Even when she's three months pregnant, she takes the one-hour-forty-minute flight from Kuching to Kuala Lumpur, continues with a five-hour drive to the project site at Mentelong where she spends three weeks in the Pahang part of Taman Negara working with the elephant team. Most nights, they camp out in the field, eating canned sardines or chicken curry with rice, and coffee with lots of sugar. 
When she is five months pregnant, Foon Yuan makes a trip to Loagan Bunut National Park where she spends eleven days in the field, mist-netting and setting hub traps. To get there, she takes a flight from Kuching to Miri followed by a four- to five-hour drive to the national park. With her husband and another field researcher, she stays at the Sarawak Forestry barracks. Every day, they trek into the peat swamp along the line transact. Again, meals are canned sardines and curry chicken, accompanied with coffee brewed with lots of sugar for energy.

These trips prepare her for journeys to new places, to Acheh and Bali, and even New York City where she leads her team in a foreign land, finding her way using the subway and on the streets, so far and different from the streets of Kuching and the forests of Borneo. "Many times, I get sent to places and I have to take care of other people and these are places I've never been before. So, people think you're so brave to go. And I'm like I don't feel very brave. It's just something you have to do."

One of the greatest challenges is when she sits in meetings with government officials. They don't see her as significant and so, often, they will say things that they wouldn't if they thought she mattered. "Use this to your advantage," Foon Yuan says. "Also, find a niche where you're useful. Take notes, make sure they're clear, and become an integral part of the project."

Working with the communities in urban and rural areas, Foon Yuan finds it harder to get through to the adults. "They're very jaded . . . they put a lot of importance on self not on the community. So when you have very selfish people, it's very difficult to work." But the best part is "actually seeing people become affected and becoming aware of nature and their surroundings and then realising that they can help to look after the environment and that it's a responsibility that they can take. It's really nice to see students go, 'Wow I can do lots of things for the environment.' The fact is they see people who are passionate about it and they see people taking steps to do it. And they're thinking, 'This is something I can do. It's not just something really powerful people can do."'

\section{A conversation with three bold women}

We sit down. On my left is a whiteboard with dates and names written on it. Straight ahead is a door leading to desks and next to it, is a wall of shelves filled with files and books. It's an old house, formerly government quarters for civil servants located at the bottom of a gentle slope on an old road which postmen recognise as Ridgeway Road, but other younger people know as Jalan Ong Tiang Swee. Like many roads named for colonial officers in pre-independence times, the road has been re-named for a new local hero. The house is hidden by thick bushes and trees, as this area has been designated a green lung. Where it once was the home and office of the single WCS wildlife biologist working in Borneo, it is now the office for about 20 staff working in the forests, longhouses, fishing and school communities. They are all homegrown Malaysian conservationists-wildlife biologists, social scientists, educators, communication officers-young men and women who are striving to build awareness about the need for conservation, and to protect the wildlife. 
Some WCS staff still see visitors from the past-white men in colonial khakis, knee-high socks and shoes. The material remnants of days past lie in the files of field notes and books left by the first wildlife biologists who worked in Sarawak: renowned wildlife biologist Dr George Schaller who came from 1959 to 1960 to survey orang-utans, and Dr Michael Kavanagh who worked on the Lanjak-Entimau Management Plan in the 1980s. The pua kumbu hanging on the wall and the carvings were left by Dr Elizabeth Bennett who lived and worked here for nearly 20 years, while the big Chinese drum was given to WCS after an athletic performance by a troupe of lion dancers who came to help usher in the Year of the Goat when Dr John Robinson visited in 2003.

Western conservationists have fanned out and spread themselves around the globe. There is no doubt that Louis Leakey's "Trimates" or "Angels" contributed to knowledge and understanding of the animals they studied; they were indeed bold women for conservation and they changed what we know about, and how we perceive, wildlife. However, we need a different kind of bold change in conservation around the world. The WCS Malaysia Program is now one of the few which is led by a Malaysian and with a team of Malaysian researchers.

I turn to the three bold women who are part of the orangutan team. They are the new generation of conservationists who will protect and care for the wildlife and their habitats. The face of conservation is not just the privileged educated white man or woman from a Western country. Here, we have indigenous conservationists who the local people trust and joke with over a meal. I ask the young women if they have role models. I expect to hear about Jane Goodall, Dion Fossey, Birute Galdikas, or even Steve Irwin, Gerald Durrell or David Attenborough.

Foon Yuan: God told humans to take responsibility of nature. Seven years for the land to lie fallow. But we're greedy, and we don't do that anymore.

Mujan Anyie: Yes, I feel the same. God called me to be here; it's my responsibility to save the Earth and the wildlife.

Selena Nala: Yes, and it's the villagers themselves, too. They know what to do, to make sure there's enough for everyone. Not all the villagers are bought over by money.

Foon Yuan: When my Bidayuh grandfather passed away, we found his letters when he was the tuai rumah (longhouse headman) appealing to the state government not to allow logging companies to clear the forests to build access roads to the village in the old Padawan area. Fifty years ago, he knew that it would be a disaster to allow large roads to be carved out of the forest even if it would make life easier for the longhouse people. My grandfather didn't need anyone to tell him this. He knew that clearing the forest would be a mistake for the people, their land and their livelihoods. We're lucky the area is hilly, so no one bothers with us now that helicopter logging no longer takes place. 
Selena Nala: I really look up to my father. He never shows his difficulties, he is always patient and never fights. He never accepted bribes [when he worked in the Customs Department]. And my old aunty. She lives alone in the village, grows her own food, rears chickens and raised her brothers and sisters when her parents could not. She can't read or write, but she is independent, caring and loving. ... What more can I do, with my education, skills and passion?

Mujan Anyie: My English teacher. She inspired me. When my scholarship was not processed in time, she told me not give up; that greater things were to come. She touched my heart and she still does.

I would like to end this story about bold women with a conversation I had with Mujan Anyie. We met several times so I could piece her story together.

You know her to be a strong young woman. She has had to be strong since she was a child, living apart from her parents since she was seven, coming home just for short holidays between school and university terms. She has lived in residential schools and hostels all these years. It is the price of an education for a young Kayan from Belaga. Recently, she was diagnosed with tuberculosis. The authorities are trying to trace where she contracted the disease. It could have been lying dormant in her all these years; it could have been contracted in any of the hostels she lived in and not necessarily back home in the longhouse.

I ask her, what did your parents tell you when you were troubled?

"They don't hug me or kiss me. They don't touch me or comfort me when I face troubles or ask for advice. I do wish they would, but that's not who they are. When I need them, I remember when I was baptised in the river when I was 14. I knew then I wouldn't be alone anymore."

Mujan Anyie says, "This is what my parents told me: Be good to everyone. Don't forget to pray. Whatever life may bring you, don't give up. You are the one who changes your own life." 